\title{
GROUP DECISION SUPPORT IN COASTAL ZONE MANAGEMENT \& POLICY ANALYSIS
}

\author{
Ernest H. Forman ${ }^{1}$, Marleen Gerrits ${ }^{2}$, and Frank R. Rijsberman ${ }^{3}$
}

\begin{abstract}
This paper illustrates how policy makers with different responsibilities can effectively participate in a group decision involving coastal zone management policy. A group decision support system is used to help structure the discussion, provide meaningfil measurements, synthesize over competing factors from different perspectives, and provide a record of the analysis for justifying and defending a policy if and when the rationale or process that led to the policy is questioned by those not involved in the deliberations.
\end{abstract}

\section{INTRODUCTION}

Some of the most resource rich zones for human and natural biological activity are located in the world's coastal zones. It is estimated that by the year 2000 , more than $75 \%$ of the world's population will live within 36 miles of a coast. Human activities cause a deterioration of ecosystems by pollution and infrastructural changes. This, coupled with natural processes such as waves, currents and floods, and further compounded by global climatic change can have a hugh impact on coastal zones around the world. In 1990, the Intergovernmental Panel on Climate Change (IPCC) recommended that nations with low lying coastal areas (which are expected to be vulnerable to the effects of sea level rise and other impacts of climate change) should develop and implement national coastal zone management plans by the year 2000. This recommendation was adopted by the United Nations General Assembly, and confirmed both in the United Nations Framework Convention on Climate Change and in the 'Agenda 21' of the United Nations Conference on Environment and Development. Agenda 21 identifies integrated management as a key program area for facilitating the sustainable development of coastal areas and calls for the preparation of national action plans which incorporate integrated coastal zone management.

1Professor of Management Science, George Washington University, Washington, D.C. 20052. FORMAN@UNIX1.CIRC.GWU.EDU

2 Environmental Software Developer, Resource Analysis, Zuiderstraat 110, 2611SJ Delft, The Netherlands. Tel:(31)-15-122622, Fax:(31)15-124892

${ }^{3}$ Managing Director, respectively, Resource Analysis, Zuiderstraat 110, 2611SJ Delft, The Netherlands. Tel:(31)-15-122622, Fax:(31)15-124892. 
As part of the implementation of these recommendations, the World Coast Conference 1993 was held in the Netherlands in November 1993. No country in the world is as dependent on effective water and coastal management as the Netherlands and the importance of the conference was underscored by the attendance of His Royal Highness Crownprince Willem-Alexander and the Dutch Minister of Transport, Public Works and Water Management, Mrs. Maij-Weggen, nine other ministers and high- level UN officials such as Mrs. Dowdeswell, Executive Director of UNEP. Altogether, 300 senior government officials, high level policy makers, and senior representatives from non-government organizations from 90 nations participated in the conference.

In addition to preparing scientific and technical reports on vulnerability assessments, coastal zone management concepts and a 'World Coast 2000' document ([1],[2] and [3]), representatives to the conference participated in the use of management concepts and tools for integrated policy making. This paper describes a coastal zone management simulation exercise and a group multi-criteria decision analysis that demonstrated the use of such management toois.

\section{SIMULATION EXERCISE}

In order to demonstrate how ministers and high level policy experts can utilize management concepts and tools for development and evaluation of integrated coastal zone management (CZM) plans, a simplified coastal area simulation model COSMO (COastal zone Simulation MOdel) was developed by Resource Analysis - Associates for Natural Resources Management Consulting. The simulation involved the example area Catopia, a rather densely populated developing region surrounding the coastal waters of Catfish Bay. Various economic activities take place in Catopia, including industry, agriculture, bauxite mining, fishing, navigation and port activities.

The overall goal is to ensure the sustainable development and use of the Catopia coastal area and improve the living conditions of the local people. Under this overall goal there are several main objectives: to enhance economic development and to improve environmental quality, while minimizing capital investments and reducing long term vulnerability (e.g. flood risk). There are several existing problems in Catopia, including:

* Unemployment and low income

* Limitations in available land and water resources

* Deterioration of coastal water quality

* Limitations in available capital to achieve desired developments

* Potential threats to coastal areas from beach erosion and flood risk

To demonstrate how to select between different CZM-plans a multi criteria analysis instrument was used to prioritize the alternative plans on the basis of the Analytic Hierarchy Process.

\section{STEPS TOWARDS A CZM-PLAN}

The development of an integrated CZM-plan entails the following activities:

- Design of alternative strategies and assessment of their anticipated consequences. 
A coastal zone management STRATEGY is a combination of:

* economic development options (to increase employment and income)

* environmental protection options

* coastal protection options

- Evaluation of the alternatives against the multiple objectives for anticipated scenarios (only one scenario will be addressed here).

- Evaluation, from each of several perspectives, (Ministers of the environment, tourism, industry/Ports and public works participated in this exercise) of the relative importance of the objectives and sub-objectives.

o Synthesis to decide on the best plan.

Coastal zone management strategies are analyzed for different SCENARIOS, including:

* demographic and macro-economic developments; and

* aspects of climate change.

Two predefined scenarios are considered:

1) BASE scenario: without accelerated climate change.

2) CCHANGE: with accelerated climate change (following IPCC scenarios).

A CASE is a combination of a CZM strategy and a scenario.

The planning task is to analyze and evaluate CZM strategies under different scenarios for Catopia. This is done in a number of steps which closely follow the approach of the Concept and Tools (CAT) document ([3]) that was prepared for WCC'93. These five steps, listed below, represent the principles of the approach of the CAT-document.

1) Analysis of the system characteristics and current future problems.

2) Determination of analysis conditions, objectives and criteria.

3) Formulation of coastal zone management strategies through selection of measures to be undertaken.

4) Analysis of individual CZM strategies through inspection of impacts for each of the criteria in detail.

5 Evaluation of a set CZM strategies by comparison and review.

Five COSMO strategies have been predefined using a combination of low or high coastal zone and/or regional development, low to high environmental protection measures and different coastal response. These strategies are outlined in Table 1. 
Table I: Overview of predefined CZM-strategies in COSMO

\begin{tabular}{|c|c|c|c|c|}
\hline Strategy & $\begin{array}{l}\text { Coastal } \\
\text { Zone } \\
\text { Devclopment }\end{array}$ & $\begin{array}{l}\text { Regional } \\
\text { Development }\end{array}$ & $\begin{array}{l}\text { Environm. } \\
\text { Protection }\end{array}$ & $\begin{array}{l}\text { Coastal } \\
\text { Protection } \\
\text { Measures }\end{array}$ \\
\hline $\begin{array}{l}1 \text { Base } \\
\text { Strategy } \\
\text { (ZERO) }\end{array}$ & $\begin{array}{l}\text { Housing at } \\
\text { Catville } \\
\text { (city); Hotels at } \\
\text { Catfish Bay }\end{array}$ & None & $\begin{array}{l}\text { No } \\
\text { additional } \\
\text { protection }\end{array}$ & $\begin{array}{l}\text { Retreat } \\
\text { (activities } \\
\text { and } \\
\text { facilities } \\
\text { are retreated } \\
\text { and } \\
\text { reinvestments } \\
\text { made) }\end{array}$ \\
\hline $\begin{array}{l}2 \text { Economic } \\
\text { Development/ } \\
\text { Retreat } \\
\text { (HED/R) } \\
80 \%\end{array}$ & $\begin{array}{l}\text { High } \\
\text { Residential } \\
\text { housing at } \\
\text { Popta } \\
\text { Beach; } \\
\text { Hotels at } \\
\text { Popta Beach }\end{array}$ & $\begin{array}{l}\text { Bauxite } \\
\text { port; } \\
\text { Irrigated } \\
\text { agriculture }\end{array}$ & $\begin{array}{l}\text { No } \\
\text { additional } \\
\text { protection }\end{array}$ & $\begin{array}{l}\text { Retreat } \\
\text { (activities } \\
\text { and } \\
\text { facilities } \\
\text { are retreated } \\
\text { and } \\
\text { reinvestments } \\
\text { made) }\end{array}$ \\
\hline $\begin{array}{l}3 \text { High Economic } \\
\text { Development/ } \\
\text { Adapt } \\
\text { (HED/A) }\end{array}$ & $\begin{array}{l}80 \% \\
\text { Residential } \\
\text { housing at } \\
\text { Popta } \\
\text { Beach; } \\
\text { Hotels at } \\
\text { Popta Beach }\end{array}$ & $\begin{array}{l}\text { Bauxite } \\
\text { port; } \\
\text { Irrigated } \\
\text { agriculture }\end{array}$ & $\begin{array}{l}\text { Waste } \\
\text { water } \\
\text { treatment } \\
\text { plant } \\
\text { (WWTP) }\end{array}$ & $\begin{array}{l}\text { Accomodate } \\
\text { (adjustments } \\
\text { are made if } \\
\text { possible or } \\
\text { less } \\
\text { favorable } \\
\text { circumstances } \\
\text { are accepted) }\end{array}$ \\
\hline $\begin{array}{l}4 \text { High } \\
\text { Economic } \\
\text { Development/ } \\
\text { Protect } \\
\text { (HED/P) }\end{array}$ & $\begin{array}{l}80 \% \\
\text { Residential } \\
\text { housing at } \\
\text { Popta } \\
\text { Beach; } \\
\text { Hotels at } \\
\text { Popta Beach }\end{array}$ & $\begin{array}{l}\text { Bauxite } \\
\text { port; } \\
\text { Irrigated } \\
\text { agriculture }\end{array}$ & $\begin{array}{l}\text { WWTP and } \\
\text { onsite } \\
\text { treatment }\end{array}$ & $\begin{array}{l}\text { Protect } \\
\text { (Adequate and } \\
\text { timely } \\
\text { protection } \\
\text { measures will } \\
\text { be taken) }\end{array}$ \\
\hline $\begin{array}{l}5 \text { Low } \\
\text { Economic } \\
\text { Development/ } \\
\text { Retreat } \\
\text { (LED/MP) }\end{array}$ & $\begin{array}{l}\text { Housing at } \\
\text { Catville } \\
\text { (city);Hotels at } \\
\text { Catfish Bay }\end{array}$ & Marine Park & $\begin{array}{l}\text { WWTP and } \\
\text { onsite } \\
\text { treatment }\end{array}$ & $\begin{array}{l}\text { Retreat } \\
\text { (activities } \\
\text { and } \\
\text { facilities } \\
\text { are retreated } \\
\text { and } \\
\text { reinvestments } \\
\text { made) }\end{array}$ \\
\hline
\end{tabular}


COSMO users first analyze five predefined cases (combinations of strategies with scenarios), namely the five strategies described above for the accelerated climate change scenario. In a second round of analysis the users can subsequently modify the strategies and scenarios to reflect their own priorities.

Evaluation of the Alternatives Against the Multiple Objectives

Four main objectives and sub-objectives to ensure sustainable development and use of the Catopia coastal area are considered:

- Economic development: enhance regional income and employment

- regional income per capita

- reduction of unemployment level

o Environmental quality:

- improved water quality measured in reduced number of violations of water quality standards

- preservation of ecosystems evidenced by the presence of a marine park

o Minimization of capital investments measured by investment expenditures

- Reduced long term vulnerability - decrease in flood risks

- future costs to maintain coastal system

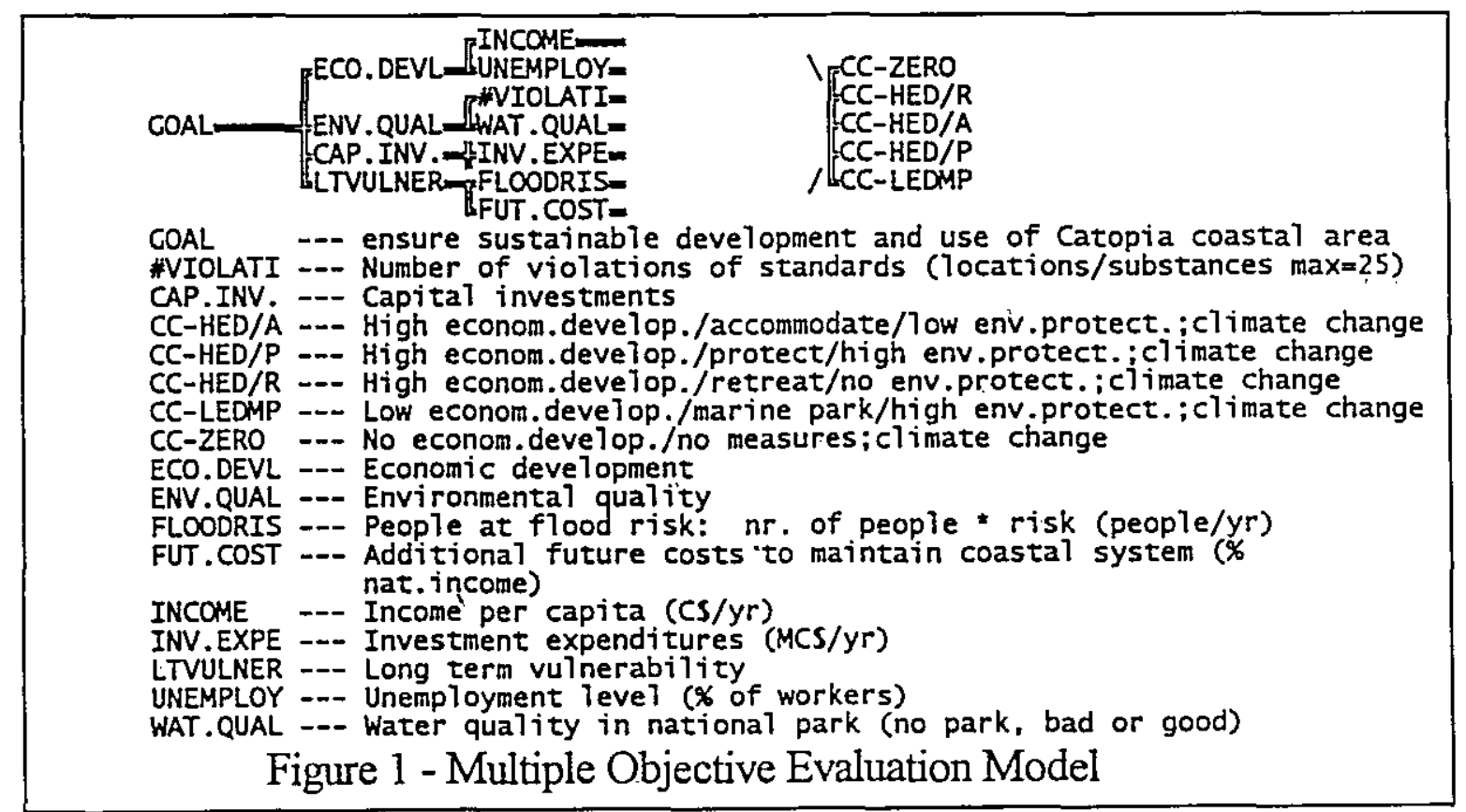

Five predefined cases are analyzed and compared with each other on the basis of their effect-scores with respect to the 7 low level criteria. Table 2 shows these raw effect-scores. 
Table 2: Raw effect-scores for all alternatives.

\begin{tabular}{|l|l|l|l|l|l|l|l|l|l||}
\hline Case & Scenario & Strategy & $\begin{array}{l}\text { Income } \\
\left({ }^{*} 1\right)\end{array}$ & $\begin{array}{l}\text { Unemp } \\
\left({ }^{*} 2\right)\end{array}$ & $\begin{array}{l}\text { \#Viol } \\
\left({ }^{*} 3\right)\end{array}$ & $\begin{array}{l}\text { W.Qual } \\
\left({ }^{*} 4\right)\end{array}$ & $\begin{array}{l}\text { Inv. } \\
(* 5)\end{array}$ & $\begin{array}{l}\text { Flood } \\
\text { Risk } \\
(* 6)\end{array}$ & $\begin{array}{l}\text { F.C. } \\
\left({ }^{*} 7\right)\end{array}$ \\
\hline $\begin{array}{l}\text { CC- } \\
\text { Zero }\end{array}$ & CCHANGE & ZERO & 10,100 & 21 & 7 & $\begin{array}{l}\text { no } \\
\text { park }\end{array}$ & 3,400 & 0 & 12 \\
\hline $\begin{array}{l}\text { CC- } \\
\text { HED/R }\end{array}$ & CCHANGE & HED/R & 9,900 & 21 & 5 & $\begin{array}{l}\text { no } \\
\text { park }\end{array}$ & 3,400 & 3 & 3 \\
\hline $\begin{array}{l}\text { CC- } \\
\text { HED/A }\end{array}$ & CCHANGE & HED/A & 9,600 & 15 & 4 & $\begin{array}{l}\text { no } \\
\text { park }\end{array}$ & 3,500 & 105 & 6 \\
\hline $\begin{array}{l}\text { CC- } \\
\text { HED/P }\end{array}$ & CCHANGE & HED/P & 8,500 & 26 & 1 & good & 3,100 & 0 & 0 \\
\hline $\begin{array}{l}\text { CC- } \\
\text { LED/MP }\end{array}$ & CCHANGE & $\begin{array}{l}\text { LED/M } \\
\text { P }\end{array}$ & 10,100 & 21 & 7 & $\begin{array}{ll}\text { no } \\
\text { park }\end{array}$ & 3,400 & 66 & 0 \\
\hline
\end{tabular}

*1 Income per capita (C\$/yr)

*2 Unemployment level (\% of workers)

*3 Number of violations of standards for all locations and substances (max. 25)

*4 Water quality in national park (no park, bad or good)

*5 Investment expenditures (MC\$/yr)

*6 People at flood risk: number of people multiplied by risk (people/yr)

*7 Additional future cost to maintain coastal system as \% of national income

Prioritization of Objectives and Alternatives

The selection of a 'best' policy entails the prioritization of objectives (and sub-objectives) as well as the prioritization of alternatives with respect to each of the objectives. (In some circumstances other factors such as scenario likelihood and player importance can also be prioritized). Using Team Expert Choice [4], the priorities of the objectives for this exercise were derived from pairwise comparisons in a group session involving policy makers representing different governmental sectors. Not only did the policy makers represent different sectors in this exercise, but they were from a wide range countries as well. Specifically the policy maker group consisted of an official from IUCN, representing the Environmental interests from the perspective of a non-government organization, a Minister of Tourism and Transport from the Seychelles, a Minister of Ports and Shipping from Sri Lanka, and a Minister of Public Works from Spain. High level policy makers from 90 countries observed as these four discussed the tradeoffs and their judgments about the relative importance of the criteria. The discussion demonstrated a finding of Phillips and Phillips [5] that "Experience in groups shows that under the right circumstances, the whole can be greater than the sum of its parts." By structuring the problem with a group decision support system, the discussion was focused on one specific issue at a time as compared to drifting from issue to issue as so often happens at meetings. As the policy makers focused on their own objectives with respect to each issue, they were able to explain their own views, offer 
information that the others might not have had, and justify the rationale of their specific judgments. Some of the judgments were made in the form of verbal pairwise comparisons. An example of one 'verbal' pairwise judgment from each the four policy makers is shown below for the comparison of the relative importance of economic development vs. environmental quality:

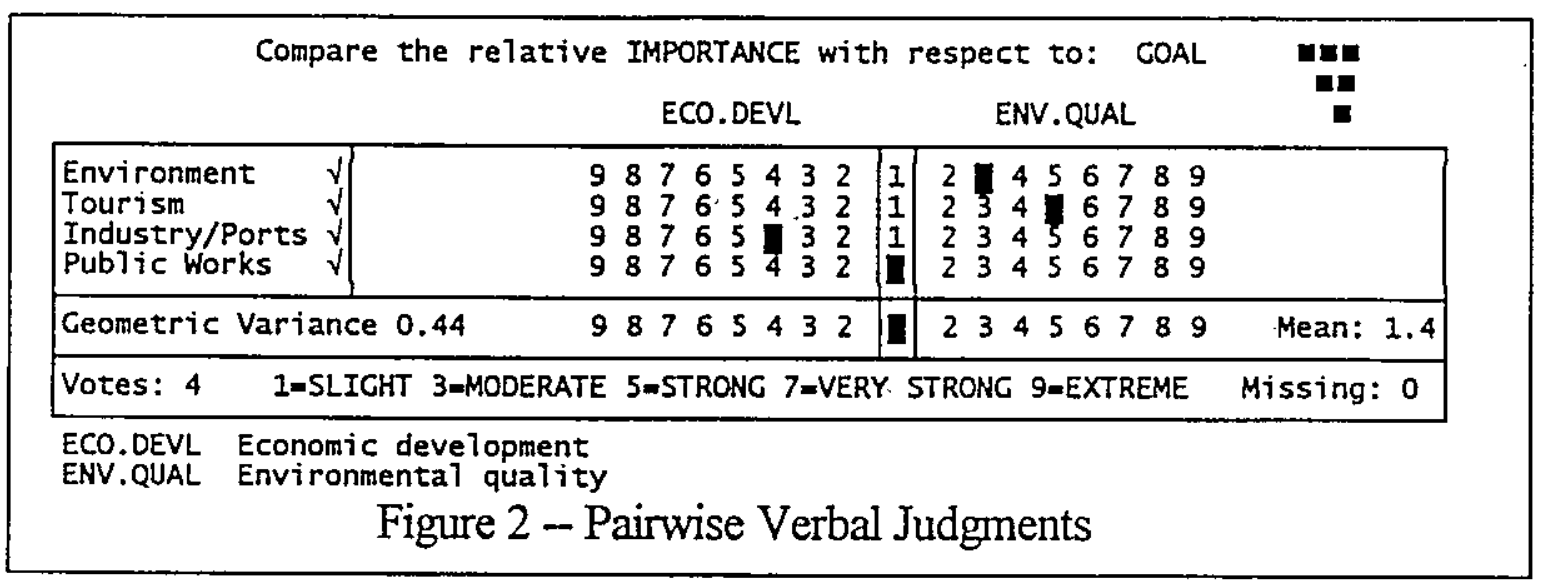

Surprisingly, there were no great "surprises" in that each of the policy makers could see the logic in the others' judgments even when they felt differently about that particular aspect of the analysis. For example, when comparing the relative importance of economic development vs. environment quality, three of the four policy makers felt that environmental quality was at least as important as economic development. However, the Sri Lanka Minister of Ports and Shipping explained that because his country was so underdeveloped, economic development was more important than environmental quality. The others understood and accepted this difference of opinion as valid. If this were a multi-national decision with multi-national impact, the ability to discuss and understand such differences in values and perspectives would be very important.

A group DSS such as Team Expert Choice can quickly identify judgments with the most variance (Figure 3 shows the comparison with the highest variance --capital investment required vs. long term vulnerability), judgments with smallest variance (Figure 4 shows the comparison -- environmental quality vs. long term vulnerability - with the least variance) and judgments where all decision makers but one are in agreement (Figure 5 shows the judgment -- environmental quality vs. capital investment -- where all but one judgment indicated that environmental quality was more important.) 


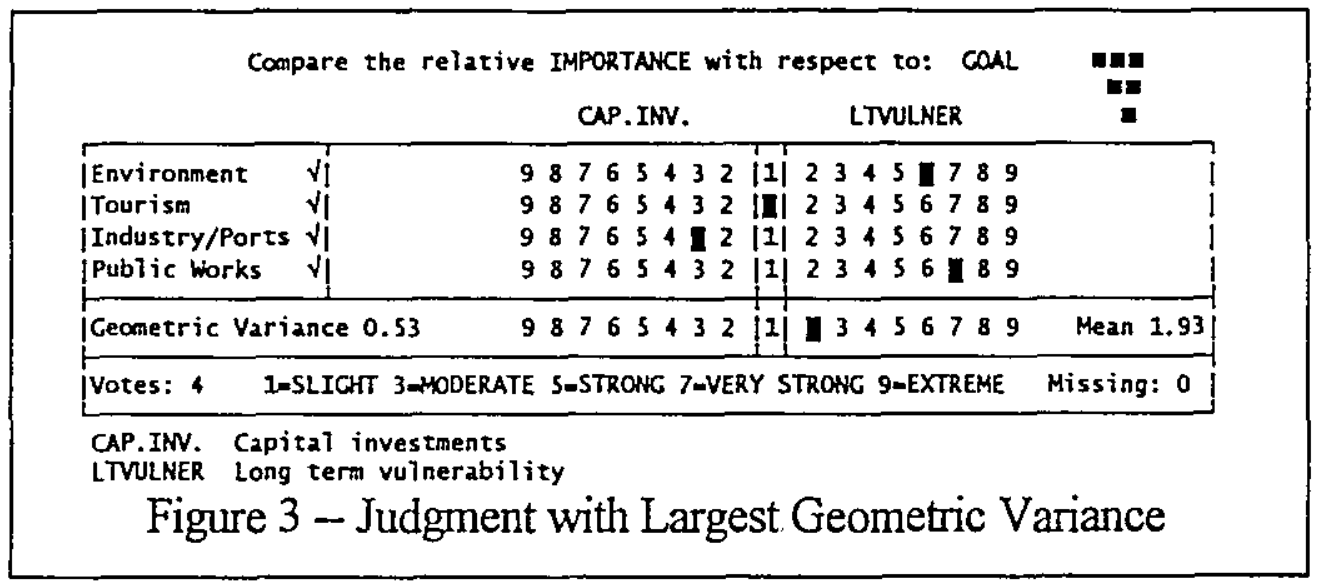

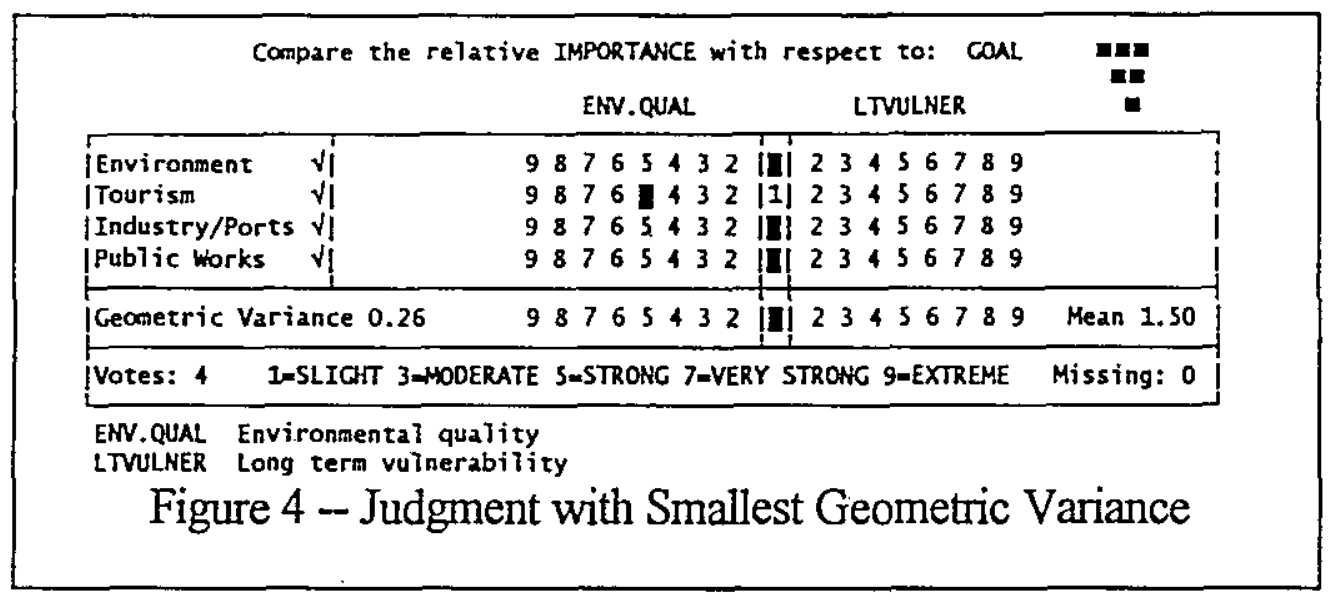

\begin{tabular}{|c|c|c|}
\hline Compare the relativ & $\begin{array}{l}\text { MPORTANCE with respect to: COAL } \\
\text { ENV.QUAL } \quad \text { CAP.INV. }\end{array}$ & man \\
\hline $\begin{array}{ll}\text { IEnvironment } & \sqrt{ } \\
\text { [Tourism } & \sqrt{\mid} \\
\text { |Industry/Ports } & \sqrt{\mid} \\
\text { |Public Works } & \sqrt{\mid} \\
\end{array}$ & 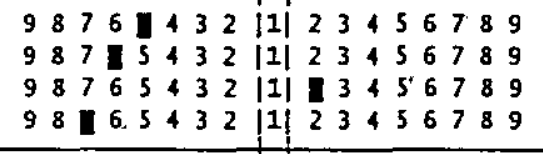 & \\
\hline Geometric Variance 0.40 & 987654121123456789 & Mean 3.20 \\
\hline INSLICHT $3+40$ & ATE 5-STRONG 7-VERY STRONC 9-EXTREME & Missing: 0 \\
\hline \multicolumn{3}{|c|}{$\begin{array}{l}\text { CAP.INV. Capital investments } \\
\text { ENV.QUAL Environmental quality } \\
\text { Figure } 5 \text { - Judgment with a "loaner" }\end{array}$} \\
\hline
\end{tabular}

Not only must the values and perspectives of the each of the decision makers be discussed and understood, it is necessary that they be measured on a suitable scale so that they can be combined with those of the other decision makers in a synthesis of all objectives, sub-objectives and alternatives in the analysis. This step, which is extremely important, is frequently overlooked or treated in a haphazard fashion when ad-hoc methods are used. Since a synthesis consists of the multiplication of priorities in one level of the model by those at the next lowest level, the priorities must be ratio level measurements. Careless use of ordinal or interval level measures, would produce mathematically meaningless results. The group DSS used here is based on the Analytic Hierarchy Process [6] which converts each pairwise judgment to a ratio, combines judgments of the individual decision makers by taking a geometric 
average, and derives ratio scale priorities from the set of the resulting judgments by calculating the normalized eigenvector corresponding to the largest eigenvalue of the pairwise comparison matrix. For example, the geometric averages of the individual judgments of the relative importance of the major objectives with respect to the Goal were:

\begin{tabular}{|c|}
\hline $\begin{array}{l}\text { JUDCMENTS WITH RESPECT TO } \\
\text { COAL }\end{array}$ \\
\hline 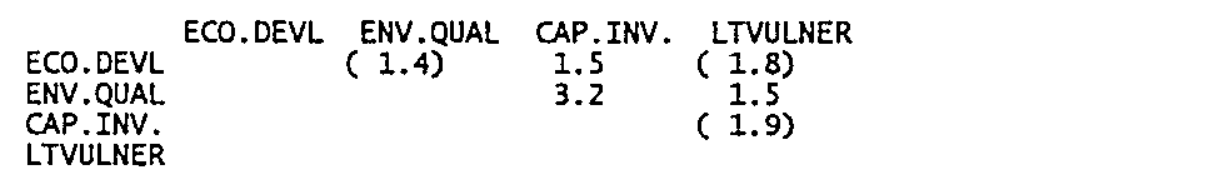 \\
\hline 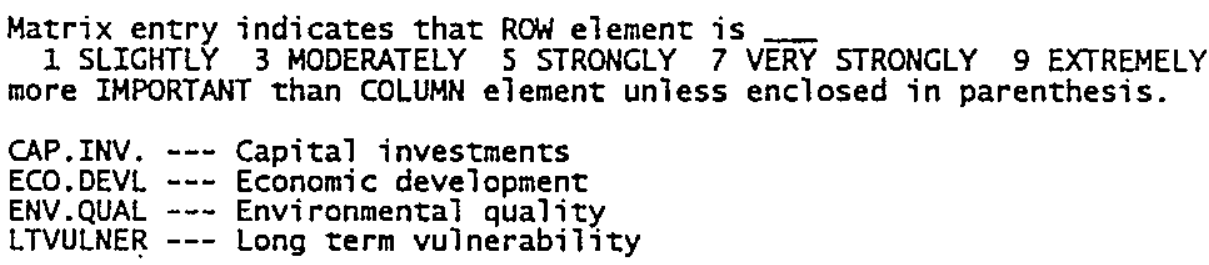 \\
\hline Figure 6 - Geometric Average of Individual Judgments \\
\hline
\end{tabular}

The resulting priorities and inconsistency ratio are shown in Figure 7:

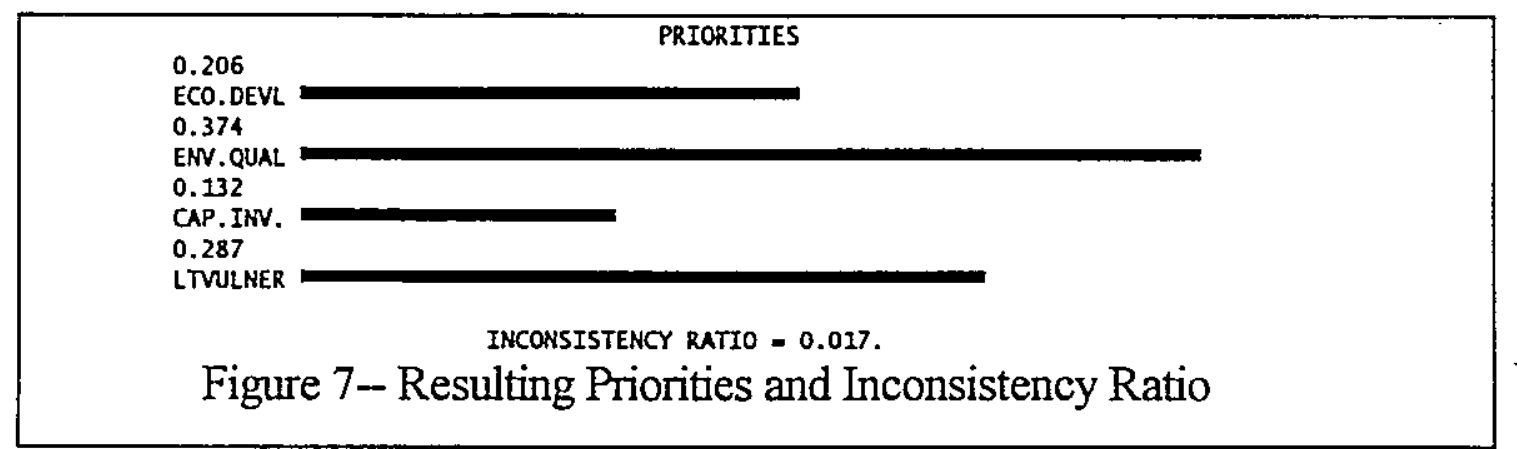

Priorities for the sub-objectives and alternatives can be derived in a similar fáshion, with several possible variations. For example, pairwise graphical judgments were made by the group for the relative importance of the sub-criteria. The priorities of the altematives were derived from pairwise comparisons on the basis of a raw effect-score table. Due to the limited time available for the group session these pairwise comparisons were made beforehand. 


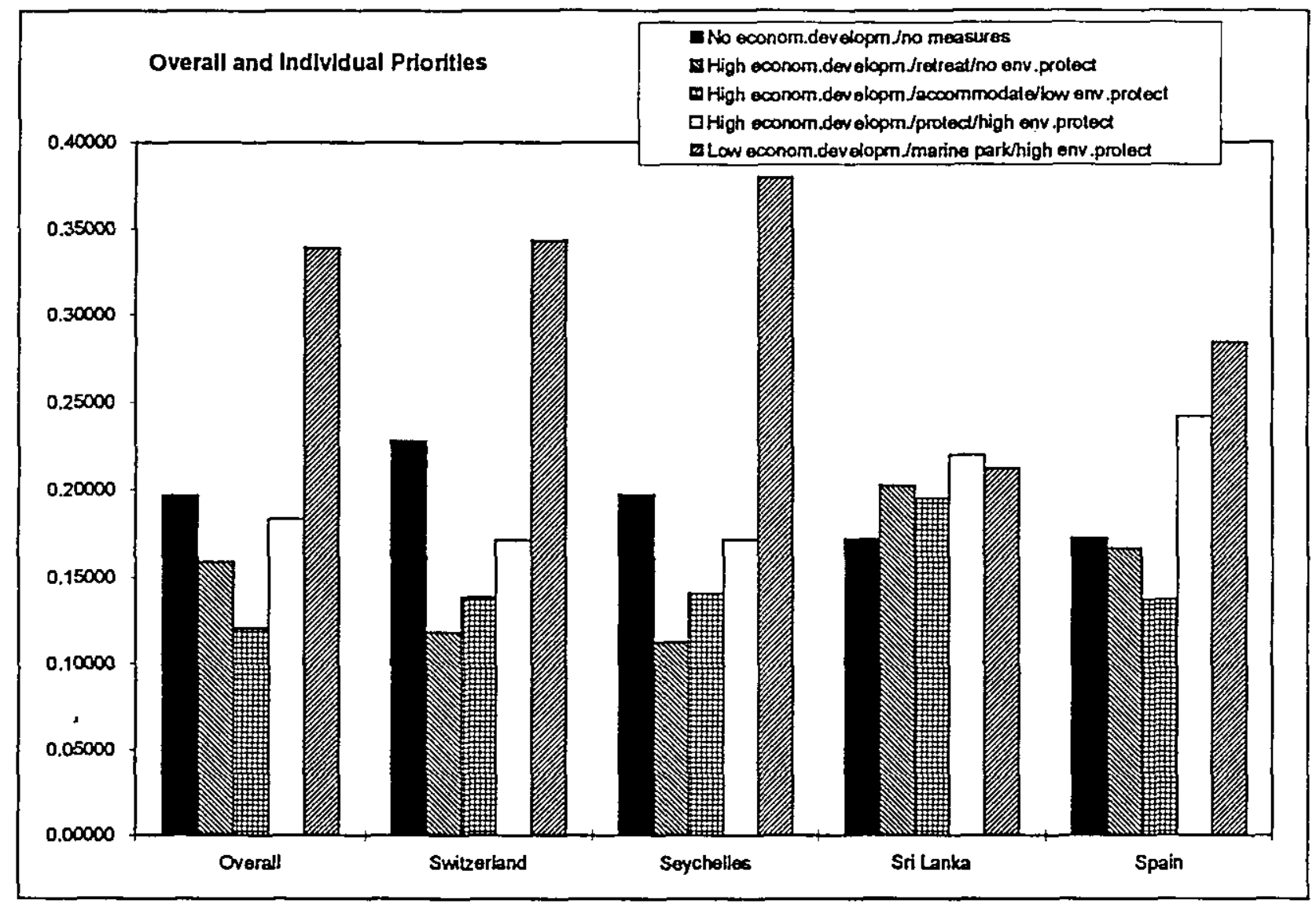

Figure 8- Overall and Individual Priorities

Synthesis

A synthesis of the priorities for each player as well as the overall priorities for the group (assuming each player had equal weight) are shown in Figure 8. The policy consisting of low economic development with a marine park and environmental protection was, overall, the most preferred alternative. It was also preferred by three of the four policy makers. Understandably, the policy maker from Sri Lanka favored the policy that included high economic development along with environmental protection. The analysis shows, however, that even for Sri Lanka, the low economic development alternative preferred by the ministers from the other countries ranked second and was very close in priority. 


\section{CONCLUSION}

This paper has illustrated how policy makers with different responsibilities can effectively participate in a group decision involving coastal zone management policy. The group decision support system provides several benefits. First, it helps structure the discussion so that values and perspectives can be clearly expressed. Areas where there is agreement and areas where there are disagreement are easily identified. The policy makers were each able to focus on their own objectives and explain/justify their specific judgments to the other policy makers. Each of the policy makers could see the logic in the others judgments. Secondly, the group decision support system allows for a meaningful measurement and synthesis of the importance of objectives, the preference of alternatives with respect to numerous competing objectives and the evaluation of other factors that may affect the decision, such as the likelihood of scenarios and the relative importance of the policy makers. There are numerous methods for analyzing (breaking down) complex problems but few that provide the means to properly synthesize (combine) information, knowledge and experience applied in the analysis. A Group Decision Support System based on the Analytic Hierarchy Process is capable of converting the groups' knowledge and experience (expressed as pairwise comparisons) to ratio scale measures that can be combined in meaningful ways.

Another benefit is having a record of how the analysis was structured, what judgments were made and by whom, what data was used to support the judgments, and how sensitive the results were to underlying assumptions. Such a record can be invaluable for justifying and defending a policy if and when the rationale or process that led to the policy is questioned by those not involved in the deliberations. Finally, the recorded results of the analysis can be of value if at a later time an evaluation of both the decision and the decision making process is undertaken in an effort to continually improve.

\section{References}

[1] IPCC (1994), Preparing to meet the coastal challenges of the 21st century, Conference Report, World Coast Conference 1993, Noordwijk, The Netherlands, 1-5 November 1993.

[2] L. Awosika, S. Boromthanarat, R Cornforth, M. Hendry, R. Koudstaal, M. Ridgley, J. Sorensen, L. de Vrees, S. Westmacott, World Coast Conference 1993, Noordwijk, The Netherlands, 1-5 November 1993.

[3] World Coast Conference 1993 Organising Committee (1993), How to account for impacts of climate change in integrated coastal zone management: Concept and tools for approach and analysis, Version 2.0, by Resource Analysis and Delft Hydraulics, World Coast Conference 1993, Noordwijk, The Netherlands, I-5 November 1993.

[4] Team Expert Choice, Expert Choice Inc., Pittsburgh, PA. 1993.

[5] Lawrence \& MaryAnn Phillips - Facilitated Work Groups: Theory and Practice J Operational Society, Vol 44, No. 6, pp 533-549.

[6] Thomas L. Saaty, The Analytic Hierarchy Process, (New York: McGraw Hill, 1980). 